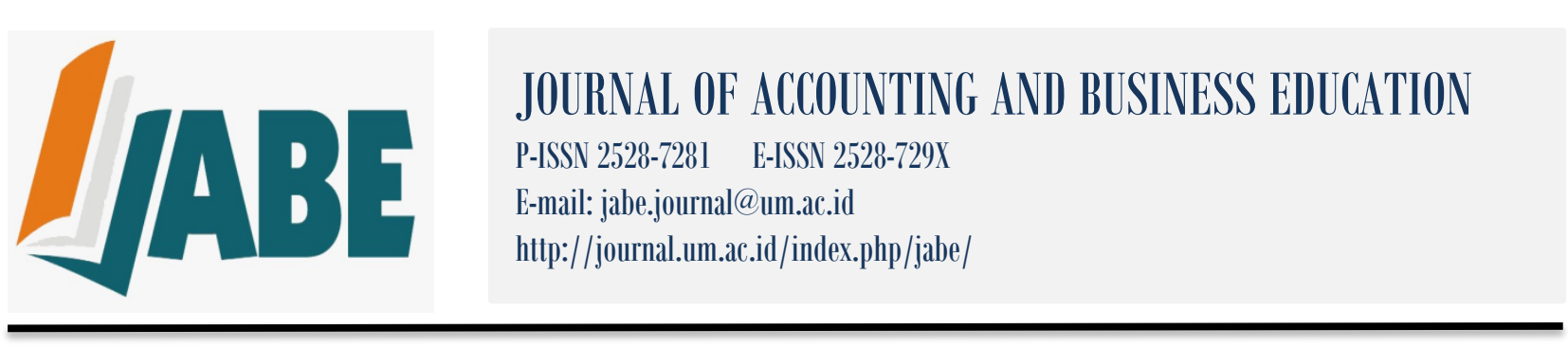

\title{
The Urgency in Implementing the Accounting Sustainability of Spiritual Dimension in the Sustainability of Company
}

\author{
Yopi Yudha Utama \\ Eko Ganis Sukoharsono \\ Zaki Baridwan \\ Universitas Brawijaya, Malang \\ yopiyudhautama@gmail.com
}

\begin{abstract}
The purpose of this paper is to understand the concept of accounting sustainability of spiritual dimension as a concept of sustainability. Sustainability accounting of spiritual dimension or can be called as Aksus is a sustainable concept which contains the spiritual dimension that complements the previous three dimensions (profit, people, and planet). This study uses the critical discourse analysis method of Norman Fairclough. The result is that there is a representation of Sukoharsono's thoughts in the text, as well as the relation to Sukoharsono's reader and identity for the readers that occur on the look of a text. Thought of concern for the survival of all beings is present in the text. At the level of discourse practice such as the production of texts, Sukoharsono does so with great caution and accordance with the sciences he has had, so it can be said if the production of the text is a manifestation of his perspective on accounting and sustainability. At the level of sociocultural practice, there is an influence of the current business situation and the social community that exists. The analysis shows Sukoharsono's commitment to the world of accounting and sustainability, and that business people always continue to care about the survival of all beings in addition to fulfilling their benefits
\end{abstract}

Keywords: Sustainability accounting, economy, social, environment, spiritual, life

\section{INTRODUCTION}

Triple bottom line is a phenomenal concept, since this concept has a purpose to protect the existence of living things and the natural environment that exists on this earth. This concept was first conceived by Elkington (1997). However, such a good concept still invites rejection from some people. One of the contradictions to the implementation of the triple bottom line is that the company's responsibility is only to the company owner. This is an inappropriate expression, because in this life there is we need each other. The operational activities of the company disturbed the community comfort and security and makes the natural environment damaged, it will only result in the company's own losses. Therefore, it is necessary to have a 
sustainability program for the company, so that in seeking the profit the company does not make damage to humans, animals, plants and nature.

The application of the triple bottom line within the company is a must. But the fact is, there are still companies that only think about their own benefits and ignore life in the place where the company conducts its operations. This is proven by the occurance of forest fires in several provinces in Indonesia, due to forced land clearing. Not only on land, ecosystems in the ocean also become threatened due to fishing using dangerous materials and illegal fishing. Such conditions should not occur continuously, because it will certainly have a dangerous impact on human life and its future generations, for the life of flora and fauna, and for the ecosystem both on land, air and sea on this earth.

Judging from several events that have a detrimental impact on life due to the actions of companies that are not responsible, then in the concept of sustainability there needs to be a new dimension or aspect. The new dimension is the spiritual dimension. The concept of sustainability by incorporating this spiritual dimension was put forward by Sukoharsono (2010). He called this concept as sustainability accounting with spiritual dimension or can be abbreviated as AKSUS. In this concept, it does not negate or eliminate all matters related to the material, but instead attempts to make it aware if there are other things besides the material that must be considered even more to the material itself. This action consists of the economic dimension, social dimension, environmental dimension and spiritual dimension. The economic dimension in the concept of accession belonging to Sukoharsono (2010) has a mission that is to fight poverty and unemployment, then for the social and environmental dimensions have a mission so that the company's operational activities are not carried out carelessly, while in the spiritual dimension has the mission of balancing the meaning of life to self, between individuals and groups of organizations.

The presence of a spiritual dimension in the concept of sustainability is a very important. The reason is that there are many smart people but do not behave correctly. The examples is people who commit corruption. Some corruption actors are people who have a good background in their academic fields, but the intelligence is inversely proportional or not in harmony with their behavior. This also applies to those who are behind the decision of several companies that do damage as well as the causes of the threat of security and comfort of life in the vicinity of where the company operates. 
The presence of a spirituality dimension is expected to be able to change the negative behavior that exists in people who do damage. Behavior is an important thing to change, because bad behavior will actually harm itself even more to others. Therefore, to change the negative behavior that occurs in people who do damage, spirituality is needed. Spirituality contains teachings as well as practices that teach humans to be able to cleanse hearts full of black stains, so that their hearts become clean again or become holy again. A clean or pure heart can produce positive thoughts and behaviors as well, so that whatever is done by that person always considers whether his thoughts or actions are in accordance with God's will or not. With thoughts and behaviors that always consider God's will, these behaviors can bring benefits to life.

Based on the background described in the paragraphs above, the identification of the problems to be examined is about the urgency of implementing sustainability accounting with a spiritual dimension in sustainable business. Thus the purpose of this paper is to determine the urgency of implementing sustainability accounting with a spiritual dimension in sustainable business.

\section{LITERATURE REVIEW AND HYPOTHESES}

\section{Sustainability}

Sustainability is not a program that will harm the company, because Gerlagh (2017) says that the concept of sustainability must be developed to support the economy, but at the same time, sustainability must truly protect the scarcity of natural resources. Meanwhile, Sudana (2016) revealed that sustainability is a terminology or concept that reflects the long-term and comprehensive sustainability and existence of life. The same thing also expressed by Finch (2005) sustainability focuses on the company's long-term corporate goals to be achieved. Therefore, there needs to be agendas to realize sustainability. In accounting, sustainability describes as a part of accounting that relates to activities, methods and systems for recording, analyzing and reporting environmental and social impacts caused by financial activities, ecological impacts and the social of a defined and perhaps most important economic system, the interaction and relationship between social, environmental and economic issues which are the three dimensions of sustainability (Schaltegger \& Burrit, 2010).

Sustainability is closely related to the triple bottom line, because this concept develops or as an initial step of development for identifying and monitoring activities that contribute to 
sustainability (Stenzel, 2010; Felisia \& Limijaya, 2014), so that it can be said if sustainability is known as the concept triple bottom line (Siswanti, Salim, Sukoharsono \& Aisjah, 2017; see also Jackson, Boswell \& Davis, 2011; Ekwueme, Egbunike, \& Onyali, 2013; Hammer \& Plvo, 2016).

\section{Spiritual Dimension of Accounting Sustainability}

The accounting concept of sustainability was first raised by Sukoharsono (2010) in his professorship inaugural address at Brawijaya University, Malang City. This concept itself is in the tenth phase in the phases of the development of social and environmental accounting. Sukoharsono (2010) in his work parses these phases which are (1) the first phase is the phase started by Howard Bowen in 1953. The Bowen concept aborts the understanding of Adagium which reads as small sacrifice to get as big a result; (2) The second phase is by Davis, who has a view if an organization must have responsibility; (3) The third phase was in 1971 which was started by the Committee for Economic Development (CED) which made a work entitled "Social Responsibilities of Business Corporations" that has three concentric circles, namely inner circle of responsibilities, intermediate circle of responsibilities, and outer circle of responsibilities; (4) The fourth phase is the first mandatory French regulation in the world. This phase discusses the issue of social and environmental in accounting reporting, so there are some changes to the detailed requirements; (5) The fifth phase is the phase in which the socialist economy began to collapse in the 1980s; (6) Sixth phase, namely social and environmental accounting that has a place in the emergence of balance scorecard; (7) The seventh phase is the contribution of Gray to social and environmental accounting. In 1993, Gray gave a different touch to sustainability accounting, namely the existence of methods sustainable cost, natural capital inventory accounting and input-output analysis. In addition, in this phase social and environmental accounting can be understood in monetary terms, because it is designed quantitatively; (8) The eighth phase, namely the emergence of the concept triple bottom line initiated by Elkington (1997). In this concept there are three main aspects, namely profit, people and planet. This concept can be said if it is not possible to seek profit to damage the social life and environmental sustainability; (9) The ninth phase is the phase of sustainability reporting accompanied by the creation of the first global reporting initiative (GRI); (10) In the last phase, namely the sociospiritualist accounting phase in which in this phase there is a spiritual aspect as a complement to the triple bottom line. The concept of sustainability in which there are economic, social, 
environmental and spiritual aspects is then called sustainability accounting with a spiritual dimension.

\section{Dimension, Indicators, Aspects, and Measuring Unit of Aksus}

The concept of aksus as well as the triple bottom line can also be applied by the company. This is because the indicators of each dimension or aspect can be measured in quantitative form or expressed in qualitative form. Quantitative representation of what is known in conventional accounting principles, such as monetary and non-monetary units, while for qualitative is shown in the form of narratives, drawings and colors which are often difficult to simplify these symbols (Sukoharsono, 2010).

Sukoharsono (2010) describes the four dimensions as follows (1) In the economic dimension consists of direct economic indicators (including aspects of consumers, suppliers, employees, investors, and the public sector) and indirect economics (including family economics, the contribution of the national economy, and international economic contribution). The measurement unit of this dimension is presented quantitatively and qualitatively; (2) Social dimension, which consists of indicators of employment practices and work feasibility, human rights, society, and product responsibility. There is a measurement unit from this dimension which is presented qualitatively and quantitatively, but there are also those that are only conducted qualitatively. It depends on the related aspects; (3) Environmental dimension, which has indicators (covering aspects of natural resources, energy, water, animal and plant diversity or biodiversity, emissions, effluent and waste, suppliers, products and services, compliance, transportation, and overall). The measurement unit of this dimension is presented qualitatively and quantitatively, except for compliance aspects which are only presented qualitatively; (4) Spiritual dimension with spiritual indicators (including sincere love, sincere love, transcendental awareness, and self contemplation ability). The measuring unit in this dimension is presented qualitatively.

\section{METHODS}

The research is qualitative research. Qualitative research is a research that obtains results or findings without statistical procedures (Strauss \& Corbin, 2003: 4). In this qualitative research, the researcher use critical discourse analysis (CDA). The choice of the method, because 
it is adjusted to the focus of the research which is to gain a deeper understanding of the text in the research data. The research data in this study is to use a text or text from the article of Sukoharsono (2010) concerning "Metamorphosis of Social and Environmental Accounting: Constructing Sustainability Accounting with Spirituality Dimension". The data was chosen because issues related to the environment still continue to occur, so it needs new ideas to minimize this. So the construction of the concept contained in the article is considered as one of the concepts that is able to minimize these problems, so that it is interesting to analyze the discourse of the concept.

Critical discourse analysis (CDA) is an analysis developed by Norman Fairclough. To obtain the results of the analysis, the authors used CDA analysis techniques from Fairclough. Within the CDA, there are three dimensions that are used as stages of analytical techniques, namely the dimension of the text (micro) which is the embodiment or meaning of a text, then the dimension of the practice of discourse (meso) which contains the relationship between the production of a discourse and the text, and the dimensions of sociocultural practices (macro ) which includes external factors that can influence a discourse contained in a media (Fairclough, 1992: 73; Aman, 2006: 75; Mayasari, Darmayanti \& Sugeng, 2012: 25).

From the analysis techniques that have been mentioned, the scheme of this research is as follows:

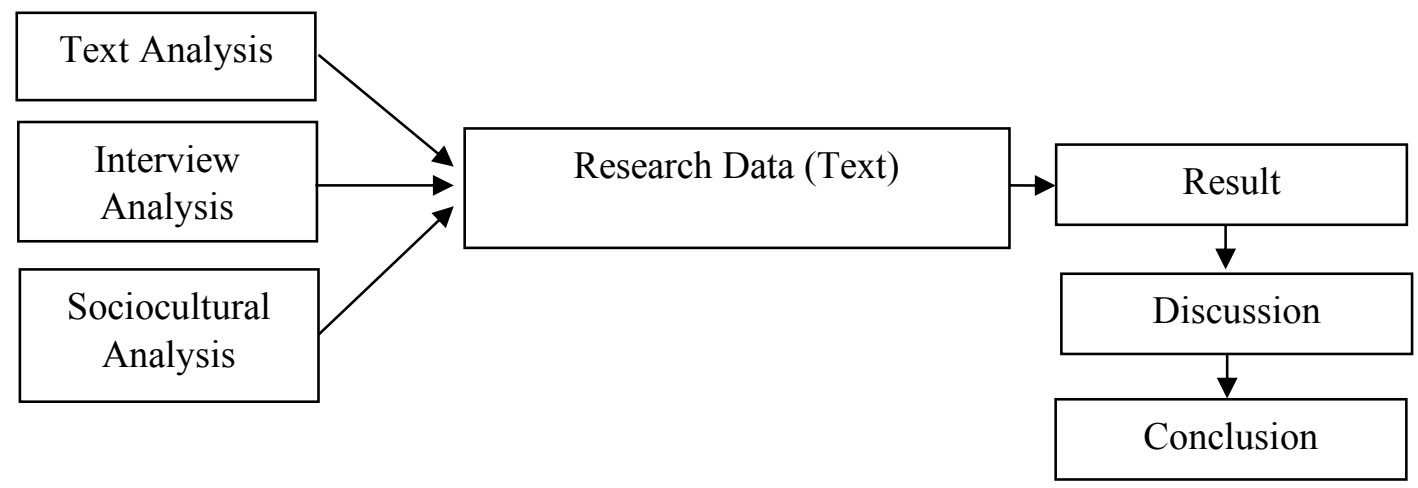

Figure 1. Research Scheme

\section{RESULTS}

\section{Text Analysis (Micro)}

Analysis on CDA has three analyzes, namely at the level of representation, level of relation and level of identity. In this study, the level of representation that will be made as an outline lies in the mission and objectives of sustainability accounting with a spiritual dimension. 
The focus of analysis on the level of representation is found in the thoughts of the text writer and the situation

\section{Representation of Eko Ganis Sukoharsono Thought}

In the background of text writing, there are a lot of words and languages of postmodernism and also references to reading that are directed to Sukoharsono. This indicates that the thinking possessed by Sukoharsono in the field of accounting is in the postmodernism paradigm. Then in the next discussion also explained about the phases of the development of social and environmental accounting. In the tenth phase, there are words of spirituality and once again many refer to Sukoharsono's references.

With the spirituality as an additional dimension of sustainability that was constructed by Sukoharsono, it can be said that Sukoharsono tries to introduce his ideas into the world that all behavior must be accounted for and also the importance of having a behavior full of love and affection. This is reflected in the purpose of the concept construction text. In these objectives, the words chosen by Sukoharsono, in two objectives, are the words "economic, social, environmental and spirituality events", while in other purposes there are "laws, norms and ethics". From the selection of these words, it can be said if a business entity must comply with the applicable rules and also act that takes into account environmental sustainability.

In the concept mission constructed by Sukoharsono, the first is on the economic dimension. The mission in this dimension is that economic growth can fight poverty and unemployment, so it needs to revitalize. The revitalization words here are interesting, because economic growth before the presence of this concept has not been able to fight poverty and unemployment. This may indicate that according to him, it is still not appropriate to use economic growth, so it needs revitalization. Then in the social and environmental dimensions, its mission is that the economic dimension does not blindly exploit its interests. These words of "economic dimension" and "blind" indicate if there is an operational activity to seek profits made by unscrupulous companies who are not responsible or not to maintain social and natural environment. Both of these words show that he is aware that he is part of the social and natural environment that is connected to each other. The last dimension is spirituality, its mission is to balance the meaning of life between individuals and groups of organizations. The words "balance the meaning of life" are interesting, because most likely these words serve as a 
reminder for him, academics, practitioners, and everyone, so that in living, the life must be balanced between the world and the hereafter.

\section{Representation of Survival}

Representation of survival is a representation of the situation of the text being studied. It is found in the words "the facts that the earth experienced a very significant change, unfortunately the change is a negative change". This situation makes people want business entities to pay attention to environmental sustainability and care for social life. These words can be interpreted as a representation of the condition of the earth which is increasingly damaged, and caused by those who are not responsible in carrying out their activities for profit seeking. Besides, what is also interesting is the existence of the words "we" in the case of the negative changes in the earth. Here it is seen if Sukoharsono is most likely to want to show that the small actions taken by us (Sukoharsono, me, or everyone) but damage the environment are also one of the causes. The use of these words "we" is also a representation of the situation that occurs, and is used as a factor to continue to improve.

\section{Relation and Identity}

Relations that occur here are indicated by the actor (Sukoharsono) or the text maker with the actors acting in an irresponsible manner. It is illustrated in an analogy found in the Avatar movie, where there is a person's behavior that damages life in other people's environments. There is a relationship that shows that behavior that destroys survival must be immediately prevented. The relation shown is also able to create a relationship between actors (teachers and environmental observers) with readers. The actor here as the creator of the concept of sustainability, also includes himself as one of the causes of damage, because there are words "we" in sentences that are essentially about the perpetrators of negative change on earth.

This relationship makes the reader more interested in the text, because of the honesty of the actor. This is able to give rise to the identity of actors towards text readers. The identity is further strengthened by the presence of aspects and the measuring unit in the indicators of each dimension of sustainability constructed by Sukoharsono. With this statement, the identity of Sukoharsono that happened to the text reader was as an academic who was very concerned about survival, even though the concept still had something to be improved. In addition, the existence of the words "we" in sentences that are essentially about the perpetrators of negative changes on 
earth, shows if he is very careful in making the text so as not to cause noise to other parties. This makes the reader have a good image of the text maker.

\section{Analisa Praktik Wacana (Meso)}

In the second dimension or the practical dimension of this discourse, as mentioned in the previous section, namely the dimension that has a relationship between the production of a discourse, and including the consumption of text in this case is the reader of a text. Therefore, the relationship can be explained in the paragraph below.

\section{Text production}

Writing on this research data is produced by the author, Eko Ganis Sukoharsono. He is a lecturer at Brawijaya University, Malang. He is a professor at the Faculty of Economics and Business in the field of accounting and sustainability. Judging from some of the writings that have been produced, it can be said that he is an academic who is also an environmental observer. Therefore, writing this article about spiritual dimension accounting for sustainability could be one of the forms of his concern about life that could be threatened due to operational activities of unscrupulous companies.

Text production carried out by Sukoharsono is based on the knowledge he has. One of them can be seen from the developmental stages of social and environmental accounting contained in the text. In addition, with a variety of activities that are inseparable from his field, the production of the writing is done very carefully. This is because it does not cause harm to any party.

\section{Text Dissemination and Consumption Text}

Dissemination can be done with print or electronic media. In writing about sustainability accounting with a spirituality dimension, using electronic media. The spread of electronic media has its own advantages, because the quality of the text can still be read even though it has been several years. But this can be problematic for those who are not used to reading with computers, laptops or other electronic media. Unlike the print media, the weakness of the print media is that when the writing has been for years it could be that the text in the text becomes unclear and difficult to read.

The spread of the text has a huge impact when it is associated with text consumption. This text consumption contains the recipient's target of a discourse. With Sukoharsono's 
educational background, as well as his tracks which continue to actively produce writing and in activities (such as seminars) in the field of accounting and sustainability, it can be said that the writings of him can influence to build an idea in relation to accounting and sustainability for academics and practitioners. So, when it is viewed in the present era, the dissemination of texts for academics and practitioners with electronic media (in the form of electronic files) is more effective and also efficient.

With the influence of Eko Ganis Sukoharsono's writing, the readers will be carried away by his views on accounting and sustainability. Judging from some of his writings, it can be concluded that accounting should not only benefit certain parties, but must be able to provide happiness for all beings. With his views as possible, it will be easy for anyone to accept his views. However, it does not rule out the possibility of parties who do not agree with his writings regarding accounting and sustainability. The existence of a disagreeing party is something that can lead to an increase in the number of discussions regarding accounting and sustainability. This is a proof of his capacity or quality and his influence in accounting and sustainability.

\section{Analysis of Sociocultural Practices (Macro)}

Making the writing in the form of "Metamorphosis of Social and Environmental Accounting: Constructing Accounting Sustainability with Spirituality Dimension" is inseparable from the context of business conditions that continue to grow starting from the single dimension of profit making to the three bottom line, namely profit search must be accompanied by attention to social conditions and the natural environment. It can be seen if the development of social and environmental accounting began in 1908 until 2010 with the emergence of this spiritual dimension of accounting sustainability. This development has become a very warm development for academics and practitioners, because the emergence of pros and cons of this.

In addition to the business situation that should be more friendly to the lives of creatures, making discourse can also be influenced by the social conditions in which the place of the discourse is located. The very religious state of society in Indonesia, making Eko Ganis Sukoharsono constructs a system of sustainability with religious aromas, which is coupled with the spiritual dimension in the concept of sustainability. The spiritual dimension which is full of love and affection and the existence of self contemplation in accordance with the character of the 
nation which is full of tenderness (affection), and manners, as well as with the diverse ethnically and cultures that exist in Indonesia.

The common thread of these conditions made the readers of Eko Ganis Sukoharsono's writings in the theme of the construction of sustainability accounting with a spirituality dimension as if they were led to the use a concept that could provide good for all beings, both the concept applied in Indonesia and outside Indonesia. This is because this concept is from Indonesian academics, but has universal values, which can be applied anywhere

\section{DISCUSSION}

\section{The Empty Space of Triple Bottom Line}

Triple Bottom Line (TBL) is an idea that results from Elkington's thought. Triple bottom line is a sustainability concept in which there are three main aspects, namely profit, people and planet. In the concept, it can be said that the search for profits carried out by business entities or organizations must not ignore human and natural concerns. Thus, TBL can be used as a decision making process and corporate evaluation (Wang \& Lin, 2007; Jackson, Boswell \& Davis, 2011). The concept of a triple bottom line within a company is usually associated with a Corporate Social Responsibility (CSR) program. One of the advantages of doing the TBL concept is maintaining the life of flora and fauna. For companies through TBL reporting (triple bottom line reporting), the benefits gained are known to be a company that is more transparent and accountable (Atu \& Kingsley, 2013).

TBL becomes a concept that can steal attention from the first time it appears. This is not surprising, because the TBL invites debate from those who disagree with its existence, as well as from those who agree with the TBL itself (see Broomhill, 2007; Sridhar \& Jones, 2013). However, the debate that occurred was actually beneficial for those who were pro on the TBL concept. This is because they may submit criticism which includes weaknesses in the TBL, so that the weaknesses can be corrected by those who are pro with TBL.

Without involving the dimensions of social (people) or nature (planet), the search for profits might be done arbitrarily, so that they can return to the single bottom line. If the business world returns to the single bottom line, it can be detrimental to environmental sustainability. This is similar to what was expressed by Galtung and Ikeda, 1999; Rich, 1996 (in Chwastiak, 1999) namely profit as an orientation from capitalism, does not contribute to increasing prosperity, but 
instead causes damage to the balance of human life through stimulation of excessive economic potential development and a decline in social conditions. However, the facts on the ground show that even though there has been triple bottom line, there are still many actions carried out by groups of companies that are not responsible in the process of seeking profit (Suartana, 2010), so that human greed in exploiting the natural and ecological environment and crippling nature will threaten human life in the future (K, 2013).

Sudana, Sukoharsono, Ludigdo, \& Irianto (2014) revealed that many claim of business institutions, especially those which cover the protection and sustainability of social and environmental assets, are still far from expectations. This is evidenced by several company activities that ignore environmental sustainability (see Koplitz et al, 2016). Judging from the problems that exist, the real problem is lust. Negative passions that lead humans to do damage. Even though humans are forbidden to do damage. Prohibition to do damage is found in QS AlA'raf verse 56, the following is the translation:

"Anddo not make mischief in the earth after it has been set in order, and call upon Him with fear and longing. Surely Allah's mercy is close to those who do good"

\section{Spirituality Dimension: Dimensions Complementing the Triple Bottom Line}

Although sustainability with the concept of triple bottom line is already there, there are still many violations committed by business entities that are not responsible for their operational activities. There is a need of new aspects to improve the behavior of people in business entities that are not responsible, namely spirituality. Ubale \& Abdullah (2015) revealed that Islamic spirituality can be used as a solution for destructive behavior. Spirituality can minimize the nature of one's ego. Selfishness is one of the bad desires that must continue to be fought. It is as expressed by Molisa (2011) and Efferin (2015) which states that if the ego is the root of the problem and each individual must minimize and even to eliminate the ego

Another reason spirituality should be able to change a person's behavior is because spirituality has the goal of keeping the heart always remember with Allah SWT. In addition, not to forget that humans were created by Allah subhanahu wa ta'ala as abdullah as well as khalifatullah fil ardh. Both as abdullah and khalifatullah fil ardh, both are human tasks in the framework of devotion to Allah subhanahu wa ta'ala. This means having consequences, namely having to carry out all the commands and stay away from all prohibitions accompanied by 
sincerity. Then each individual must continue to erode his sense of selfishness, so that he continues to be on the path that Allah subhanahu wa ta'ala understands.

The Aksus with its spiritual dimension which covers all three other aspects, namely economic, social and environmental, is a complete concept to the need of maintaining environmental sustainability, so this is what is meant by the presence of this access not to revoke everything in the triple bottom line, but to complete the space that is still empty. Triyuwono (2016) revealed that to overcome the problem by eliminating the materialistic aspect and being replaced with a spiritual dimension, it is an action that will actually add to the problem. This is because there will be a life that is not balanced between the afterlife and world life.

The dimensions of spirituality in the concept of Aksus can be used to change the mindset of life. An example is the costs incurred as a result of social activities and nature conservation carried out by the company. For them, the emergence of these costs can be seen as something that can reduce their income in the current year. When this continues to occur in their mindset, the demand to become a company with a positive image, both in terms of social and nature conservation activities, will be balanced by greater exploitation activities (due to the large costs of implementing CSR). On the contrary, with the existence of spirituality in the Aksus which consists of elements such as affection and sincere love (Sukoharsono, 2010), the costs incurred will reduce the profits of the company in the current year, these costs will actually be seen as profits and bring benefits for the company. If such a mindset is carried out continuously, it can lead to sincerity, so that the results obtained by the company will be a blessing. Isn't the blessing result an extraordinarily great favor?

\section{Advantages of Implementing Aksus}

The advantages in applying the concept of Aksus who provide reports both presented quantitatively and qualitatively (depending on the aspects that have been determined in each dimension) include in addition to the nominal value of the company carrying out the activities contained in each dimension. it can be known the reason or explanation of the company doing these things, and also the reason for not doing that. This can minimize misunderstandings when companies do not (or delay) sustainability activities. Just imagine, when there is a misunderstanding and spreading information everywhere, it can cause the company to have a negative image, so this is clearly very detrimental to the company. 
Quantitative and qualitative presentations are important to do and can make the company more transparent. This importance is almost the same as expressed by Burrit \& Saka (2006) and Siskawati, Sukoharsono, Rosidi \& Ghofar (2016) which states if it is important to separate economic and non-economic aspects in environmental accounting management. The separation of information on these two aspects is important because each information has a different function (Siskawati, Sukoharsono, Rosidi \& Ghofar, 2016).

The presentation of the spiritual dimension in the sustainability report contains the company's activities in carrying out these spiritual practices that can have its own benefits. One of the benefits is that it can attract investors (although the purpose of creating a sustainability report that contains this quadrangle bottom line is not used as an attraction for investors). Especially investors from those who have qualified religious knowledge. Of course they want to invest in companies that carry out their activities do not violate the rules, so as not to cause harm to life on this earth, because they understand that doing damage on earth is an act that is prohibited by religion.

\section{CONCLUSION}

Representation of Sukoharsono's thoughts in the text is something that cannot be passed away. As a teacher and professor in the field of accounting and sustainability (as well as an environmental observer), his thoughts on this matter were manifested in the text. This is evident from his perspective that must run a business in accordance with the applicable rules, and maintain the survival of existing creatures. The words chosen in the text, especially in the purpose and mission of the counsel indicates that environmental protection is a matter that must be done by business entities, but also must be done by everyone.

The making of the text or manuscript about the concept from Sukoharsono is likely to be influenced by the environmental situation on the earth. This is evident from the discussion that highlights the sentences regarding some of the negative changes that exist on the earth. In addition, from the sociocultural aspect, the presence of the spiritual dimension in the concept in this text is likely to be influenced by the social conditions of the surrounding community.

The problem of pros and cons about the concept of sustainability is a natural thing, because indeed differences of opinion (scientific) that arise are things that cannot be avoided. The existence of differences of opinion is a beauty of its own, so it is not justified to blaspheme one 
another. But what needs to be remembered for those who are opposed to sustainability is that those who run the company are human, and will definitely be in contact with other humans and also with nature. This relationship can never be separated or separated at any time, therefore maintaining and respecting the right to life between creatures is very important.

Sustainability is not an action that will negate or eliminate economic activities oriented to profit seeking. On the contrary, in sustainability it still maintains these economic activities, but not necessarily in the process must destroy other lives, in this case the social and natural environment. One of the concepts in sustainability is that accounting for sustainability has a spiritual dimension or can be called as Aksus.

Aksus is a sustainability concept in which contains a spiritual dimension that complements the previous three dimensions, namely profit, people and planet. The presence of this spiritual dimension is expected to change destructive behavior. The need for a spiritual dimension in the concept of sustainability can be said to be a necessity, because the worsening conditions of life on earth are due to the activities of irresponsible people who are unable to maintain life on earth.

By applying Aksus that presents both quantitatively and qualitatively data (depending on the aspects that have been determined in each dimension) the company has its own advantages. By presenting the data qualitatively, the report user can find out the condition of the company and understand the company's reasons when it does not do (one or several) such sustainable activities. The data presented qualitatively is important to do, so there is no misunderstanding. If there is a misunderstanding, plus the easier information can spread everywhere, the company has image a negative, and of course it can harm the condition of the company.

Some of the above are the conclusions and implications of the application of the Aksus after being analyzed by analysis techniques that are in accordance with the research method in this study. This research is far from perfect, due to several things, including the script is too long to be analyzed, so that at the level of text analysis becomes less focused. Therefore, the suggestion for future researchers is to analyze the text or text that is not too long, with the aim that the analysis of the text is more focused, so that the results can be deeper.

\section{REFERENCES}

Aman, I. 2006. Bahasa dan Kepemimpinan Analisis Wacana Mahathir Mohammad. Bangi: Penerbit Universiti Kebangsaan Malaysia. 
Atu \& Kingsley, O-E. O. (2013). Triple Bottom Line Accounting: A Conceptual Expose. IOSR Journal of Business and Management, 13(4), 30-36.

Broomhill, R. (2007). Corporate Social Responsibility: Key Issues and Debates. Dunstan Paper 1 .

Retrievewed

from:

https://www.google.com/url?sa=t\&rct=j\&q=\&esrc=s\&source=web\&cd=7\&cad=rja\&uact $=8 \&$ ved=0ahUKEwihi7uLxZTWAhWIQo8KHRSfACEQFghkMAY\&url $=$ https $\% 3 \mathrm{~A} \% 2$ F\%2Fwww.dunstan.org.au\%2Fdocs\%2FDunstan_Papers_No_1_2007.pdf\&usg=AFQjC NHcQNshcguWgja TNvkFMxehaXhqg.

Burritt, R. L., \& Saka, C. (2006). Environmental management accounting applications and ecoefficiency: case studies from Japan. Journal of Cleaner Production, 14(14), 1262-1275. http://doi.org/10.1016/j.jclepro.2005.08.012.

Chwastiak, M. (1999). Deconstructing the Pincipal-Agent Model: A View From the Bottom. Critical Perspectives on Accounting 10, 425-441.

Efferin, S. (2015). Akuntansi, Spiritualitas dan Kearifan Lokal: Beberapa Agenda Penelitian Kritis. Jurnal Akuntansi Multiparadigma 3(3), 466-480.

Ekwueme, C. M., Egbunike, C. F., \& Onyali, C. I. (2013). Benefits of The Triple Bottom Line Disclosure on Corporate Performance: An Exploratory Study of Corporate Stakeholders. Journal of Management and Sustainability, 3(2), 79-91. http://dx.doi.org/10.5539/jms.v3n2p79.

Elkington, J. (1997). Cannibals with forks: The tripple bottom line of 21th century business. Oxford: Capstone Publishing Ltd.

Fairclough, N. (1992). Discourse and Social Change. Cambridge: Polity Press.

Felisia, \& Limijaya, A. (2014). Triple Bottom Line dan Sustainability. Bina Ekonomi Majalah Ilmiah Fakultas Ekonomi Unpar 18(1).

Finch, N. (2005). The Motivations for Adopting Sustainability Disclosure. MGSM Working Paper 2005-17. Macquire Graduate School of Management: Sydney. Retrievewed from https://papers.ssrn.com/sol3/papers.cfm?abstract id=798724

Gray, R. 1993. Accounting for the environment. London: Paul Chapman.

Gerlagh, R. (2017). Generous Sustainability. Ecological Economics 136, 94-100.

Hammer, J., \& Pivo, G. (2016). The Triple Bottom Line and Sustainable Economic Development Theory and Practice. Economic Development Quarterly, 31(1), 1-12. https://doi.org/10.1177/0891242416674808.

Jackson, A., Boswell, K., \& Davis, D. (2011). Sustainability and Triple Bottom Line reportingWhat is it all about?. International Journal of Business, Humanities and Technology, $1(3), 55-59$.

K, A. (2013). Impact of Deforestation on Climate Change. IOSR Journal of Environmental Science, Toxicology And Food Technology 4(2); 24-28.

Koplitz, S. N., Mickley, L. J., Marlier, M. E., Buonocore, J. J., Kim, P. S., Liu, T., ... Myers, S. S. (2015). Public health impacts of the severe haze in Equatorial Asia in September October 2015: demonstration of a new framework for informing fire management strategies to reduce downwind smoke exposure. Environmental Research Letters, 11(9), $1-10$.

Mayasari, Darmayanti, N., \& Riyanto, S. (2012). Analisis Wacana Kritis Pemberitaan "Saweran Gedung KPK" Di Harian Umum Media Indonesia. JLT-Jurnal Lingustik Terapan 2(2), 22-31. 
Molisa, P. (2011). A Spiritual Reflection On Emancipation And Accounting. Critical Perspective on Accounting 22, 453-484.

Siskawati, E., Sukoharsono, E. G., Rosidi, \& Ghofar, A. (2016). Why Is Non-Economic Information Important to Carbon Disclosure? Accounting and Finance Review 1(1), 3442.

Siswanti, I., Salim, U., Sukoharsono, E. G., \& Aisjah, S. (2017). Sustainable Business of Islamic Bank Through on the Islamic Corporate Governance and Islamic Financial Performance. Journal of Finance and Banking Review 2(2), 15-20.

Sridhar, K. \& Jones, G. (2013). The Three Fundamental Criticsm of The Triple Bottom Line Approach: AN Empirical Study to Link Sustainability Reports in Companies Based In The Asia-Pasific Region and TBL Shortcomings. Asian Journal of Business Ethics, 2(1), 91-111. https://doi.org/10.1007/s13520-012-0019-3.

Stenzel, P.L. (2010). Sustainability, the Tripple Bottom Line, and the Global Reportung Initiative. Global Edge Business Review 4(6).

Strauss, A. \& Corbin, J. (2003). Dasar-dasar Penelitian Kualitatif. Yogyakarta: Pustaka Pelajar.

Suartana, I. W. (2010). Akuntansi Lingkungan dan Triple Bottom Line Accounting: Paradigma Baru Akuntansi Bernilai Tambah. Jurnal Bumi Lestari 10(1), 105-112.

Sudana, I. P. (2016). Accounting Policy Making: A Polotical Avenue for Sustainability Agenda. Procedia-Social and Behavioral Sciences 219, 732-740.

Sudana, I. P., Sukoharsono, E. G., Ludigdo, U., \& Irianto, G. (2014). A Philosophical Thought on Sustainability Accounting. Research Journal of Finance and Accounting 5(9), 1-10.

Sukoharsono, E. G. (2010). Metamorfosis Akuntansi Sosial dan Lingkungan: Mengkonstruksi Akuntansi Sustainabilitas Berdimensi Spiritualitas. Pidato Pengukuhan Guru Besar, Senin 13 Desember 2010, Universitas Brawijaya. Retrievewed from https://www.google.com/url?sa=t\&rct=j\&q=\&esrc=s\&source=web\&cd=1\&ved=0ahUKE wjcw6b2gI3WAhVEjJQKHbNxC7MQFggpMAA\&url=http\%3A\%2F\%2Faccounting.feb .ub.ac.id $\% 2$ Fwp-content $\% 2$ Fuploads $\% 2 F 2012 \% 2$ F04\%2FPidato-Pengukuhan-Guru-

Besar-Eko-GanisSukoharsono.pdf\&usg=AFQjCNHJDN mC1atNMVfoRsDL6GDtswPjw

Triyuwono, I. (2016). Taqwa: Deconstructing Triple Bottom Line (TBL) to Awake Human's Divine Consciousness. Pertanika J. Soc. Sci \& Hum 24(S), 89-104.

Ubale, A. Z., \& Abdullah, A. H. (2015). The Effect of Spirituality In Shaping The Human Behaviour (AN Islamic Perspective). International Journal of Academic Reseacrh in Business and Social Sciences, 5(9), 1-13. http://dx.doi.org/10.6007/IJARBSS/v5-19/1793

Wang, L., \& Lin, L. (2007). A Methodology Framework for the Triple Bottome Line Accounting and Management of Industry Enterprises. Internaltional Journal of Production Research, 45(5), 1063-1088. 